\title{
PENINGKATAN KEMAMPUAN MEMBACA PEMAHAMAN SISWA DAN SIKAP SISWA MELALUI MODEL PEMBELAJARAN KONTRUKTIVISME (STUDI EKSPERIMEN KUASI PADA SEKOLAH DASAR)
}

\author{
Faqih Hakim Hasibuan \\ Fakultas Hukum Universitas Muslim Nusantara Al-Washliyah Medan \\ Jalan Sisingamangaraja, No. 2, Harjosari III, \\ Medan Amplas, Medan Kota, Kota Medan, Sumatera \\ E-mail: faqihhakimhsb@yahoo.com
}

\begin{abstract}
Abstrak
Keterampilan membaca merupakan keterampilan yang sangat unik serta berperan penting bagi pengembangan pengetahuan. la juga sebagai alat komunikasi bagi kehidupan manusia. Pengajaran membaca yang paling efektif mungkin adalah pengajaran membaca yang didasarkan pemahaman yang baik tentang proses membaca itu sendiri dan yang mendorong penguasaan strategi-strategi membaca yang tepat, tetapi harus diakui bahwa tidak ada definisi yang paling tepat.

Abstract

Reading skills are skills that are very unique and important role for the development of knowledge. He also as a communication tool for human life. Teaching reading is probably the most effective teaching of reading is based on a good understanding of the reading process itself and which encourage mastery of reading strategies appropriate, but it must be admitted that there is no definition of the most appropriate.
\end{abstract}

Kata Kunci: Kemampuan, Membaca, dan Pemahaman

Pendahuluan 


\section{Faqih Hakim Hasibuan}

Isu-isu yang bertalian dengan rendahnya mutu pendidikan telah menjadi isu central yang banyak ditulis dan diperbincangkan, baik dalam forum resmi maupun tidak resmi. Tudingan itu sudah menjadi lingkaran setan antara perguruan tinggi, pengembang kurikulum, pusat-pusat diklat guru, sekolah menengah atas, sekolah menengah pertama, sekolah dasar, masyarakat, dan akhimya kembali lagi ke perguruan tinggi dan terus begitu tidak akan berakhir.

Pendidikan dasar yang dianggap sebagai fondasi yang harus dilalui dan diperlukan setiap warga negara, baik untuk melanjutkan pendidikan ke jenjang yang lebih tinggi maupun sekedar untuk hidup, tetap menjadi sorotan tajam dari berbagai pihak. Para pengamat dan pakar pendidikan menilai bahwa siswa SD sekarang dinilai hanya pandai menghafal. Mereka cenderung tidak mampu memecahkan masalah yang menuntut berpikir analisis dan logis.

Sampai saat ini masyarakat masih belum puas terhadap hasil pembelajaran bahasa Indonesia yang diharapkan. Hal ini terbukti dengan banyaknya keluhan bahwa lulusan pendidikan dasar masih belum terampil berbahasa Indonesia, baik secara lisan maupun tulisan Guru bahasa Indonesia harus lapang dada menerima untuk sementara, sambil berusaha memperbaikinya. Keadaan seperti ini dipengaruhi oleh berbagai faktor antara lain guru, siswa, sarana prasarana, situasi serta lingkungan.

Sehubungan dengan hal tersebut, Sumardi (1998) menguraikan masalah pembelajaran bahasa Indonesia sebagai berikut: (a) guru lebih banyak menekankan teori dan pengetahuan bahasa daripada mengemukakan keterampilan berbahasa; (b) bahan pembelajaran tidak relevan dengan kebutuhan siswa untuk berkomunikasi, baik secara lisan maupun tertulis, tetapi banyak berkisar pada pembahasan unsur bahasa, seperti fonologi, morfologi, dan sintaksis dan kurang menekankan keterampilan menggunakan unsur-unsur tersebut; (c) proses belajar mengajar lebih banyak didominasi oleh guru, yang berarti kurang memberikan kesempatan kepada siswa untuk mengembangkan potensinya, serta (d) struktur bahasa tercerai berai, kurang integratif, serta kurang 
menekankan aspek kebennaknaan keterampilan berbahasa secara komprehensif.

Pada era informasi dan komunikasi seperti sekarang ini, kegiatan membaca menjadi salah satu bagian terpenang dalam kehidupan manusia. Aktivitas membaca, juga merupakan prasyarat penting bagi siapa pun untuk beroleh kemajuan. Menurut Iskandarwassid dan Sunendar (2008: 245), Keterampilan membaca merupakan keterampilan yang sangat unik serta berperan penting bagi pengembangan pengetahuan, dan sebagai alat komunikasi bagi kehidupan manusia. Dikatakan unik karma tidak semua manusia, walaupun telah memiliki keterampilan membaca, mampu mengembangkannya menjadi alat untuk memberdayakan dirinya. Dikatakan penting bagi pengembangan pengetahuan karena persentase transfer ilmu pengetahuan terbanyak dilakukan dengan kegiatan membaca. Oleh sebab Itu, tepatlah apabila Harras dan Sulistianingsih (1998: 13) menyebutnya sebagai conditio, sine qua non atau prasyarat mutlak bagi setiap orang yang ingin beroleh kemajuan.

Membaca adalah salah satu keterampilan berbahasa yang sangat penting, karena keterampilan ini memiliki banyak fungsi dalam kehidupan manusia, bahkan membaca pun merupakan salah satu faktor paling penting dalam menentukan keberhasilan akademik seseorang. Namun, penduduk Indonesia lebih sutra menghabiskan waktu di depan televisi ketimbang membaca. Hal ini sesuai dengan penelitian intemasional International Education Achievement (IEA) tabun 2000 yang melaporkan bahwa siswa SD Indonesia menduduki urutan ke-38 menduduki urutan ke-34 dari 39 negara dalam hal kemampuan membaca. Persoalan ini menibutuhkan penyelesaian dengan segera, dari mana kita hares memulai mengkaji dan menganalisisnya.

Minat membaca ini tentunya patut mendapatkan perhatian serius karena minat baca mempunyai kaitan erat atau dapat mempengaruhi proses belajar anak. Oleh karena itu, untuk mengatasi masalah tersebut diperlukan sebuah penelitian, yang mendalam.

Isu bahwa kemampuan membaca siswa Sekolah Dasar dan Sekolah Menengah Pertama di Indonesia masih rendah akan menjadi fokus utama 


\section{Faqih Hakim Hasibuan}

dari penelitian ini. Isu ini tentunya patut mendapatkan perhatian serius karena kemampuan membaca mempunyai kaitan erat atau dapat mempengaruhi proses belajar anak. Oleh karena itu, kegiatan ini akan berusaha memaparkan faktor-faktor yang menyebabkan rendahnya kemampuan membaca siswa Sekolah Menengah Pertama, khususnya di SD Swasta PAB Medan Estate. Selain itu, kegiatan ini dirancang untuk memberikan alternatif pengajaran membaca yang memiliki potensi untuk meningkatkan kemampuan membaca tersebut. Pengajaran membaca altematif ini adalah penerapan model belajar kontruktivisme, yang keektifannya telah diuji melalui eksperimen oleh para guru Sekolah Menengah Pertama di Amerika Serikat. Model pengajaran ini memiliki karakteristik-karakteristik universal yang dapat diterangkan dalam lingkungan budaya dan pendidikan yang berbeda. Model tersebut akan diperkenalkan kepada para guru Sekolah Dasar sebagai satu alternatif bagi pengajaran membaca, khususnya untuk meningkatkan kemampuan membaca siswa Sekolah Menengah Pertama.

Guru perlu memikirkan proses ini untuk membangun satu landasan yang baik guna membantu siswa belajar membaca secara efektif dan efesien. Tentunya setiap orang setuju bahwa tujuan akhir dari kegiatan membaca adalah memahami makna, tetapi ada sejumlah pandangan yang berbeda mengenai bagaimana proses membaca berlangsung. Namun sebagian besar pengajaran membaca didasarkan pada satu dari ketiga pandangan berikut (Weaver, 1988: 15), yaitu (1) belajar membaca berarti belajar melafalkan kata-kata, (2) belajar membaca berarti belajar mengidentifikasi kata dan memahami maknanya, Berta (3) belajar membaca berarti belajar membawa makna ke dalam teks untuk memperoleh makna dari teks.

Pandangan pertama tampak didasarkan pada asumsi bahwa setelah kata diucapkan, maka maknanya akan muncul. Pandangan kedua berasumsi bahwa setelah makna setiap kata ditentukan atau diketahui, makna keseluruhan (paragraf, teks) akan muncul. Berbeda dengan kedua pandangan tersebut, pandangan ketiga berasumsi bahwa makna tidak muncul dari identifikasi setiap kata dalam kalimat, tetapi muncul dari 
interaksi konstan antara pikiran pembaca dan bahasa teks.

Berdasarkan ketiga pandangan diatas maka definisi membaca pun dapat dirumuskan dengan berbagai cara yang berbeda. Pengajaran membaca yang paling berhasil mungkin pengajaran membaca yang didasarkan pemahaman yang baik tentang proses membaca itu sendiri dan yang mendorong penguasaan strategi-strategi membaca yang tepat, tetapi hares diakui bahwa tidak ada definisi yang paling tepat. Selama ini, definisi membaca bersumber pada pandangan sosiopsikologis dan pandanganpandangan lain, tetapi pandangan sosio-psikologis lebih dapat diterima daripada pandangan-pandangan lain.

Kemampuan membaca kelas VI SD Swasta PAB Medan Estate juga masih rendah. Berdasarkan hasil studi pendahuluan yang peneliti lakukan melalui wawancara dengan guru dan studi pengamatan di kelas (tanggal 7, 8 dan 9 Oktober 2013), diperoleh informasi bahwa siswa secara umum baru mampu menjawab pertanyaan secara literal yang terkait dengan isi bacaan. Para siswa pada umumnya gagal ketika mereka diminta menceritakan kembali isi bacaan. Hal tersebut menunjukkan bahwa dalam membaca pemahaman siswa ternyata belum mampu menemukan ide-ide pokok paragraf, belum mampu menemukan pola hubungan antaride, belum mampu menemukan ide utama bacaan, dan belum mampu mencentakan kembali isi bacaan menggunakan kata-kata sendiri. Selama ini para. siswa hanya menerima pemahaman dan guru tanpa mereka tabu dan paham maksud bacaan itu sendiri.

Kegagalan siswa dalam memahami isi bacaan temyata sejalan dengan kesulitan-kesulitan membaca pemahaman yang didefinisikan oleh Rofi'uddin (1997: 4) bahwa pada umumnya dalam membaca pemahaman, siswa masih mengalami kesulitan dalam hal "mengenali ide pokok dan ide penjelas, mencari hubungan antaride, mencari inferensi dan mengorganisasikannya".

Belum mampunya siswa VI SD Swasta PAB Medan Estate dalam menemukan ide-ide pokok pada setiap paragraf menemukan pola hubungan antaride, menemukan ide utama bacaan, Serta belum mampu menceritakan kembali isi bacaan dengan kata-kata sendiri, diduga 


\section{Faqih Hakim Hasibuan}

disebabkan oleh belum optimalnya pelayanan guru terhadap perkembangan kognitif dan perkembangan bahasa siswa, baik pada aktivitas prabaca, saat baca, maupun pascabaca.

Dari hasil pengamatan di kelas, diperoleh temuan bahwa pada tahap prabaca, guru hanya menjelaskan kata-kata sukar yang belum dipahami maknanya oleh siswa. Pada tahap saat baca, beberapa siswa hanya diberi tugas membaca secara bergilir, dan pada tahap pascabaca, siswa hanya diminta menjawab pertanyaan-pertanyaan bacaan. Kegiatan menceritakan kembali isi bacaan hanya diberikan kepada siswa yang tergolong pandai tanpa bimbingan, sehingga hasilnya masih belum sesuai dengan harapan guru.

Di dalam pembelajaran membaca, guru belum melatih siswa untuk menemukan ide-ide pokok paragraf, menemukan pola hubungan antaride dalam bacaan, menemukan ide utama bacaan, belum melatih siswa mendayagunakan skemata yang dimilikinya untuk berinteraksi dengan teks bacaan sebagai media untuk memahami dan menceritakan kembali isi bacaan. Padahal menghargai dan mendayagunakan skemata siswa dalam memahami struktur isi bacaan sangat dibutuhkan oleh siswa VI SD Swasta PAB Medan Estate yang sedang berada dalam taraf perkembangan kognitif "operasional konkret" dan perkembangan bahasanya sedang berada dalam tahap perkembangan "kreatif". Sementara menurut Piaget (Dzoretzky, 1990: 254) tahap perkembangan operasional konkret (7-11 tahun) ditandal oleh adanya kemampuan siswa dalam berpikir logis, dapat memahami konstruksi konversasi, rangkaian/urutan, klasifikasi, dan menghitung angka-angka. Perkembangan bahasa pada tahap kreatif menurut Smith, Goodman, dan Meridith (Rubin, Dorothy, 1995. 27) ditandai oleh kemampuan siswa dalam menggunakan katakata abstrak, menyusun konsep, menggunakar kalimat urituk mengemukakan gagasan dan pendapat, serta dapat menggunakan ungkapan-ungkapan yang lazim didengar dari lingkungan.

Kurang optimalnya pembelajaran membaca pemahaman pada siswa kelas VI SD Swasta PAB Medan Estate seperti yang telah disebutkan, kiranya perlu segera diatasi/diperbaiki. Perbaikan tersebut perlu dilakukan secara menyeluruh yakni meliputi aspek perencanaan, pelaksanaan dan evaluasi. 
Sehubungan dengan hal tersebut, maka pembelajaran membaca di kelas ini perlu beralih dari model belajar konvensional yang dilandasi oleh asumsi bahwa "pengetahuan dapat dipindahkan secara utuh dari pikiran guru ke pikiran siswa" ke model belajar modem di antaranya adalah model belajar kontruktivisme. Model ini berdasarkan asumsi bahwa "pengetahuan dibangun di dalam pikiran siswa". Dalam model belajar konvensional guru banyak memfokuskan diri pada upaya penuangan pengetahuan ke dalam pikiran siswa, tanpa memikirkan gagasan-gagasan yang sudah ada pada diri siswa. Guru berpikir bahwa setelah proses pembelajaran, di dalam pikiran siswa terdapat tiruan pengetahuan yang persis dengan pengetahuan yang dimilikinya. Hal ini telah menimbulkan kegagalan dalam proses pembelajaran membaca pemahaman karena membaca pemahaman mcrupakan keterampilan pemahaman literal, nalar, dan pengonstruksian gagasan yang perlu pengembangan pikiran oleh siswa itu sendiri. Keterampilan membaca pemahaman tidak dapat dipindahkan secara utuh dari pikiran guru ke pikiran siswa, tetapi keterampilan membaca hares dibangun oleh siswa itu sendiri.

Keberhasilan penerapan model belajar kontruktivisme yang diterapkan dalam bidang sains yang diaplikasikan dalam pembelajaran dengan pendekatan sains, teknologi, dan masyarakat sudah menunjukkan keberhasilan yang memuaskan di Indonesia (Hidayat, 1996). Dalam pembelajaran pemahaman membaca bahasa Indonesia konsep-konsep kontruktivisme ini belum diterapkan.

\section{Perumusan Masalah}

Masalah yang akan dicari jawabannya melalui penelitian ini adalah dirumuskan sebagai berikut. "Apakah model pembelajaran kontruktivisme dapat meningkatkan kemampuan membaca pemahaman siswa dalam pembelajaran membaca bahasa Indonesia di kelas VII SMP?. Permasalaaan ini dirumuskan menjadi permasalahan-permasalahan yang lebih operasional sebagai berikut.

1. Bagaimanakah pelaksanaan model pembelajaran kontruktivisme dalam meningkatkan kemampuan siswa membaca pemahaman di VI SD 


\section{Faqih Hakim Hasibuan}

Swasta PAB Medan Estate?

2. Bagaimanakah kemampuan awal dan akhir membaca sera meningkatan kemampuan siswa VI SD Swasta PAB Medan Estate dalam memahami bacaan dengan model pembelajaran kontruktivisme?

3. Apakah model belajar konstruktivisme efektif dalam meningkatkan kemampuan membaca pemahaman siswa VI SD Swasta PAB Medan Estate?

4. Bagaimana kualitas pembelajaran membaca pemahaman dengan menggunakan model pembelajaran kontruktivisme?

5. Bagaimana sikap siswa terhadap model belajar kontruktivisme dalam pembelajaran membaca pemahaman?

\section{Tujuan Penelitian}

Sejalan dengan rumusan masalah tersebut, maka penelitian ini bertujuan untuk mendeskripsikan kemampuan siswa kelas VI SD Swasta PAB Medan Estate dalam membaca pemahaman. Secara lebih khusus tujuan penelitian ini dapat dirinci, yaitu:

1. Mendeskripsikan proses pelaksanaan model pembelajaran kontruktivisme dalam meningkatkan kemampuan siswa membaca pemahaman di VI SD Swasta PAB Medan Estate

2. Mendeskripsikan kemampuan awal dan akhir membaca serta peningkatan kemampuan siswa VI SD Swasta PAB Medan Estate dalam memahami bacaan dengan model pembelajaran kontruktivisme;

3. Mengetahui keefektifan pembelajaran membaca nemahaman siswa VI SD Swasta PAB Medan Estate melalui model pembelajaran kontruktivisme;

4. mendeskripsikan kualitas pembelajaran membaca pemahaman dengan menggunakan model pembelajaran kontruktivisme;

5. mengetahui seiauthnana sikap siswa terhadap model belajar kontruktivisme dalam pembelajaran membaca pemahaman.

\section{Hipotesis}

Hipotesis yang diajukan dalam penelitian ini adalah,

Ho : Penggunaan model belajar kontruktivisme tidak efektif untuk 
meningkatkan kemampuan siswa dalam memahami dan menceritakan kembali isi bacaan

H1 : Penggunaan model belajar kontruktivisme efektif dapat meningkatkan kemampuan siswa dalam memahami dan menceritakan kembali isi bacaan.

Dari hipotesis alternatif tersebut dijabarkan hipotesis-hipotesis sebagai berikut.

1. Setelah mendapat perlakuan, siswa menunjukkan peningkatan dalam aspek organisasi yang lebih tinggi daripada sebelum siswa mendapat perlakuan

2. Setelah mendapat perlakuan, siswa menunjukkan peningkatan dalam aspek pemahaman bacaan dan menguasai makna teks.

3. Setelah mendapat perlakuan, siswa menunjukkan peningkatan dalam aspek literal, inferensial, elaborasi, dan evaluasi bacaan yang lebih tinggi daripada sebelum siswa mendapat perlakuan

\section{Difinisi Operasional}

Dalam upaya memudahkan pemahaman dan menghindari kesalahan penafsiran terhadap berbagai istilah yang digunakan dalam penelitian ini, maka perlu dikemukakan definisi operasionalnya.

Model Pembelajaran adalah pola (cara, ragam, contoh, upaya, dsb) yang secara sadar dipilih dan digunakan guru dalam proses belajar mengajar untuk mencapai tujuan.

Membaca Pemahaman adalah kegiatan membaca dengan tujuan untuk memahami isi bacaan. Dalam proses kegiatan membaca pemahaman, aktivitasnya terkait dengan proses menentukan ide-ide pokok pada setiap paragraf dalam bacaan, menemukan pola hubungan antaride, menemukan ide utama bacaan, dan menceritakan kembali isi bacaan.

Kontruktivisme adalah suatu filsafat kognitif yang berpandangan bahwa pengetahuan itu adalah hasil kontruksi (bentukan) dari kegiatan/tindakan siswa itu sendiri. Pengetahuan ilniah itu berevolusi, bersifat sementara, tidak statis, dan merupakan proses. Proses kontruksi dan reorganisasi itu berlangsung secara terus-menerus dalam diri siswa. 


\section{Faqih Hakim Hasibuan}

Pendekatan ini mengenggap bahwa pemahaman dan pengetahuan yang dimiliki siswa adalah hasil konstruksiu secara aktif siswa itu sendiri. (Suparno, 1997: 38). Siswa tidak sekedar meniru dan membentuk bayangan dari pengetahuan yang diamati atau diajarkan oleh guru, tetapi secara aktif menyeleksi, menyaring, memberi arti dan menguji kebenaran atas informasi yang diterimanya. Pengetahuan yang dikonstruksi siswa merupakan hasil interpretasi dan berpikir kritis siswa itu sendiri terhadap peristiwa atau informasi yang diterimanya.

Tahap pembelajaran membaca pemahaman adalah tahap-tahap kegiatan yang terdiri atas tahap prabaca, tahap saat baca, dan tahap dalam interaksi belajar mengajar pemahaman.

Skemata adalah pengetahuan atau pengalaman awal siswa yang terkait dengan judul bacaan yang dapat digunakan sebagai dasar untuk memahami isi bacaan pemahaman yang dilakukan oleh guru dan siswa. Dalam KBM, kegiatan semacam ini biasa disebut apresepsi. Prabaca adalah tahap awal kegiatan pembelajaran membaca.

Saat baca adalah tahapan saat dilakukannya proses kegiatan membaca oleh siswa. Pada tahap ini siswa melakukan pemahaman isi bacaan dengan cara menemukan ide-ide pokok maupun ide penjelas bacaan sekaligus menentukan pola hubungan antaride sambil menguji prediksi isi bacaan yang telah ditetapkannya pada tahap kegiatan prabaca.

Pascabaca adalah kegiatan yang dilakukan siswa dalam rangka memahami isi bacaan, dan menceritakan kembali isinya dengan menggunakan kata-kata siswa baik secara lisan maupun tertulis.

Menceritakan kembali isi bacaan adalah aktivitas mengungkapkan kembali isi bacaan yang berupa pengungkapan ide-ide pokok paragraf dan ide utama bacaan yang disampaikan dengan menggunakan kata-kata siswa secara runtut, singkat dan sistematis baik secara lisan maupun tertulis

\section{Model Pembelajaran Kontruktivisme Pengertian}

Istilah kontruktivisme (contructivism) digunakan dengan berbagai makna dan telah dimulai tahun 1710 oleh "filosof kognitif". Giambatista Vico 
menyatakan "seseorang hanya dapat dikatakan mengetahui sesuatu bila seseorang dapat menjelaskan" (Yager, 1994 dan Philip, 1998: 1). Lebih lanjut Philio menyatakan bahwa pembelajar bukan penerima informasi yang pasif, tetapi 'active learner'.

Kontruktivisme menurut Piaget (Suparno, 1997:38) adalah suatu konstruksi (bentukan) dari kegiatan/tindakan seseorang. Kontruktivisme juga menyatakan bahwa pengetahuan ilmiah itu berevolusi, bersifat sementara, tidak statis, dan merupakan proses; proses kontruksi dan reorganisasi yang terus-menerus; pengetahuan bukanlah sesuatu yang ada diluar, tetapi di dalam diri seseorang yang membentuknya. Dengan demikian, kontruktivisme yang dikemukakan Piaget bersifat personal dan individual yang lebih menekankan pada proses internal.

Yager (1992: 14-16) mengajukan model kontruktivisme yang di dalamnya terdapat cara belajar dan perubahan pembelajaran. Maka kontruktivisme dapat berarti bahwa setiap manusia (pembelajar) menempatkan bersama-sama gagasan dan struktur yang dimaknai oleh seseorang untuk dipelajari. Pengetahuan harus diperoleh dalam personalsense, tidak dapat ditransfer dari seseorang ke pada orang lain seperti mengisi pembuluh darah, tetapi memerlukan personal commitment untuk menyatakan, menjelaskan dan menguji penjelasan agar memperoleh kebenaran. Dengan demikian, dapat dikatakan bahwa teori belajar kontruktivisme lebih menekankan pada pembangunan ilmu pengetahuan seseorang dengan mengacu pada sumber belajar atau sumber ilmu pengetahuan, baik yang berasal dari luar maupun dari dalam diri seseorang yang secara aktif dapat membangun pengetahuan dan menempatkannya dalam konstelasi kognisinya.

Menurut pandangan konstruktivisme, pengetahuan yang dimiliki oleh setiap individu adalah hasil konstruksi secara aktif individu itu sendiri. Individu tidak sekedar meniru dan membentuk bayangan dari pengetahuan yang diamati atau diajarkan oleh guru, tetapi secara aktif menyeleksi, menyaring, memberi arti, dan menguji kebenaran atas informasi yang diterimanya. Pengetahuan dikonstruksi siswa merupakan hasil interpensi siswa itu sendiri terhadap peristiwa atau informasi yang diterimanya. Para 


\section{Faqih Hakim Hasibuan}

pendukung kontruktivisme berpendapat bahwa pengertian yang dibangun setiap siswa dapat berbeda dengan pengetahuan yang diajarkan guru (Katu, 1999:2).

Para pendukung konstruktivisme menganjurkan dalam proses pembelajaran jaran agar terbuka peluang teriadinya tawar-mcnawar intelektual antara siswa dengan guru dan juga antarsiswa sendiri. Pokokpokok yang dibahas juga sebanyak mungkin dikaitkan dengan pengalaman siswa.

Untuk itu, perlu dirancang model pembelajaran yang diawali dengan kegiatan yang merancang siswa untuk mengungkapkan pemahaman mereka mengenai pokok yang akan dibahas.

Kontruktivisme digunakan sebagai acuan untuk membangun kelas yang memaksimalkan siswa belajar (Tobin, (Ikk, 199:47), mencari tabu hal-hal yang telah diketahui siswa (Osborne \& Freyberg, 1985: 82), memaksimalkan interaksi sosial antarteman agar dapat bernegosiasi makna, dan memperoleh berbagai pengalaman bagaimana cara membangun makna dan' temannya.

Mengenai pengaruh kepercayaan guru kontruktivisme terhadap kinerja guru dalam melaksanakan pembelajaran telah dilakukan penelitian oleh beberapa ahli. Misalnya, Hashweh (1996: 61) menemukan adanya pengaruh positif kepercayaan guru kontruktivisme terhadap penggunaan strategi efektif yang menyebabkan siswa mengubah konsepnya secara khusus. Loucks-Horsly, dkk. (1990: 133-134) menyebutkan beberapa cara agar belajar ilmu pengetahuan lebih efektif, yaitu pertama, merefleksikan belaiar kontruktivisme; kedua, menggunakan interdisipliner; ketiga meliputi asumsi historis dan filsafat secara konteks; keempat, membantu guia menghubungkan sains, teknologi, dan isu sosial; kelima, menggunakan strategi pembelajaran; keenam; mengenalkan pemecahan masalah; dan ketujuh, kolaborasi antara berbagai cabang lima dan bidang kajian.

Dengan pandangan itu maka karakteristik iklim pembelajaran yang sesuai dengan konstruktivisme dapat dijelaskan sebagai berikut.

a. Siswa tidak dipandang sebagai sesuatu yang pasif melainkan individu yang memiliki tujuan serta dapat merespon situasi 
pembelajaran berdasarkan konsep awal yang dimilikinya.

b. Guru melibatkan proses aktif datam pembelajaran yang memungkinkan siswa mengkonstrtiksi pengetahuannya.

c. Pengetahuan bukanlah sesuatu yang datang dan luar, melainkan melalui seleksi secara personal dan sosial.

Iklim pembelajaran tersebut menuntut guru untuk (a) mengetahui dan mempertimbangkan pengetahuan awal siswa: (b) melibatkan siswa dalam kegiatan aktif di kelas, dan (c) memperhatikan interaksi sosial dengan mefibatkan siswa dalam diskusi kelas maupun kelompok.

Mengajat menurut prinsip kontruktivisme adalah proses membantu seseorang untuk membentuk pengetahuannya sendiri. Dengan demikian, dapat dikatakan tugas guyru dalam proses ini lebih menjadi mitra yang aktif bertanya, merangsang pemikiran, menciptakan persoalan, membiarkan siswa mengungkapkan gagasan dan konsepnya secara kritis, dan menguji konsep siswa. Yang paling penting adalah menghargai dan menerima pemikiran siswa apapun adanya sambil menunjukkan apakah pemikiran itu jalan atau tidak. Guru harus menguasai bahan secara luas dan mendalam sehingga lebih fleksibel dalam menerima gagasan siswa yang berbeda.

\section{Bacaan dan Membaca}

Pengertian bacaan dalam penelitian im, mengacu pada satuan kebahasaan terbesar atau wacana (discourse) yang tersaji secara tertulis. Di dalam pembelajaran bahasa, satuan kebahasaan ini disebut "wacana tulis". Wacana lain yang berupa percakapan, pidato, dan khutbah disebut "wacana lisan". Wacana yang demikian ini tidak dapat disebut bacaan.

Kridalaksana (1993: 231) dalam kamus linguistiknya memberikan makna wacana sebagai satuan bahasa terlengkap yang dalam hierarki gramatikal merupakan tataran tertinggi atau terbesar. Bentuknya dapat berupa "karangan utuh" seperti novel, buku seri ensiklopedi, dan dapat pula berupa bagian dari karangan seperti paragraf, kalimat, atau kata yang membawa amanat lengkapfarigan (1987: 22) memberikan batasan yang hampir sama dengan Kridalaksana, tetapi masih melengkapinya dengan unsur kohesi dan koherensi tinggi, berkesinambungan, memiliki bagian awal 


\section{Faqih Hakim Hasibuan}

dan akhir yang nyata, disampaikan secara lisan atau tertulis.

Menurut Kamus Besar Bahasa Indonesia, Moellono (1991: 1005), wacana dimaknai sebagai ucapan, perkataaa atau tutur; keseluruhan tuturan yang merupakan kesatuan; dan kesatuan bahasa terlengkap yang realisasinya berbentuk karangan utuh, seperti novel, buku, atau artikel. Jadi, wacana bisa berbentuk lisan maupun tulisan.

Stubbs (1983) dalam Supamo Martutik, (1998: 113) memaknai wacana sebagai penggunaan bahasa untuk berkomunikasi dalam konteks sosial secara nyata. Bentuknya dapat berupa "rangkaian ujaran" atau "rangkaian kalimat". Dalam kaitan ini, rangkaian ujaran atau rangkaian kalimat merupakan dua istilah yang digunakan dalam konteks yang berbeda. Rangkaian ujaran, digunakan dalam konteks komunikasi lisan, sedangkan rangkaian kalimat digunakan dalam komunikasi fulls yang lazim disebut teks atau bacaan. Pendapat ini sesuai Goodman (1988: 130) yang menyatakan bahwa teks atau bacaan, merupakan media penyalur informasi, penyampai maksud, tujuan, pengetahuan yang disajikan dalam bentuk tertulis.

Bacaan, dalam penelitian ini diberi makna yang sama dengan wacana tertults, yaitu penggunaan "rangkaian kalinat" yang berkesinambungan, memiliki kohesi dan koherensi, Serta memiliki awal dan akhir yang nyata. Realisasinya berbentuk karangan utuh yang disebut bacaan atau teks dan biasa terclapat di dalam buku, surat kabar, dan majalah. Adapun penggunaan "rangkaian ujaran" dalam komunikasi sosial secara nyata, tidak termasuk dalam pengertian bacaan.

Sedangkan membaca merupakan salah satu aspek keterampilan berbahasa yang hares dibina dan dikembangkan secara terus menerus. Dengan aktivitas membaca, seseorang dapat memperoleh berbagai informasi yang berguna untuk kehidupannya. Dupuis (1982: 17) mengatakan bahwa "membaca merupakan sumber informasi yang utama dalam situasi belajar". Dikatakan demikian, karena informasi-informasi yang diperoleh dari aktivitas tersebut, dapat memperluas wawasan pengetahuan dan cakrawala berpikir pembacanya. Oleh karena itu. Misdan dan Harjasujana (1987: V) mengatakan bahwa "peranan membaca dalam masyarakat modem semakin jelas dan penting". Lebih lanjut mereka menegaskan bahwa: 
anggota masyarakat yang "iliterat" dan "aliterat" akan terkucilkan hidupnya. Anggota masyarakat yang iliterat atau yang beta wacana dan masyarakat yang aiterat atau yang malas membaca itu hidupnya akan selalu terkucilkan karena tuna informasi sehingga tidak dapat mengikuti kemajuan zaman bersama anggota masyarakat lainnya yang selalu tanggap, terhadap informasi yang diperolehnya (Misdan dan Harjasujana, 1987:V).

Membaca merupakan suatu keterampilan yang bersifat apresiatif, rumit, dan kompleks. Dikatakan demikian, karena berbagai faktor sating berhubungan dan berkoordinasi dalam menunjang terhadap pemahaman bacaan. Dalam proses ini terlibat aspek-aspek berpikir seperti mengingat, memahami, membandingkan, membedakan, menganalisis, dan mengorganisasikan yang saling bekeda sama untuk menangkap makna yang terdapat dalam suatu wacana secara utuh dan menyeluruh.

"Membaca adalah suatu proses yang dilakukan serta dipergunakan oleh pembaca untuk memperoleh pecan, yang hendak disampaikan oleh penulis melalui media kata-kata atau bahasa tulis". (Hodgson dalam Tarigan. 1990: 7). Suatu proses yang menuntut agar kelompok kata yang merupakan suatu kesatuan akan terlihat dalam suatu pandangan sekilas, dan agar makna kata-kata secara Individual akan dapat diketahui. Kalau hal ini tidak terpenuhi, maka pesan yang tersurat dan yang tersirat tidak akan tertangkap atau dipahami, dan proses membaca itu tidak terlaksana dengan baik (Hodgson, melalui Tarigan, 1986: 7). Dengan demikian. membaca sebenarnya merupakan suatu proses penggalian informasi dani suatu teks.

Dan segi linguistik, membaca adalah suatu proses penyandian kembali lambang-lambang grafis yaitu mengembangkan kata-kata tulis dengan makna bahasa lisan, mencakup mengolah tulisan menjadi bunyibunyi yang bermakna (a recording and decoding process). Aspek pembacaan sandi (decoding) adalah menghubungkan kata-kata tulis (written word) dengan makna bahasa lisan (oral language meaning) yang mencakup pengubahan tulisan/cetakan menjadi bunyi yang bermakna (Anderson, 1972: 209-210). Dari segi lain, membaca adalah memetik serta 


\section{Faqih Hakim Hasibuan}

memahami arti atau makna yang terkandung dalam bahasa tulis. Hal ini sejalan dengan pendapat Smith dan Robinson (1980: 6) yang mengatakan bahwa "membaca merupakan kegiatan aktif untuk dapat mengerti pesan atau informasi yang hendak disampaikan penulis". Ahli lain mempertegas bahwa "membaca merupakan pengenalan kembali lambang-lambang tubs yang digunakan sebagai stimulus untuk mengetahui arti yang ditimbulkan melalui pengalaman pembaca pada waktu la-npau" (Bond, 1979: 5). Pendapat tersebut memberikan gambaran bahwa membaca bukanlah kegiatan yang pasif. Dikatakan demikian, karena aktivitas membaca bukan hanya memetik makna, melainkan lebih jauh dari hal itu, merupakan proses pembentukan makna yang dilakukan secara terpadu dengan sesuatu yang berada di luar wacana.

Sejalan dengan pendapat di atas, Baradja (1990: 105) mengemukakan bahwa "membaca adalah suatu aktivitas dimana si pembaca mencoba memahami ide-ide penulis melalui suatu teks." Memahami suatu teks tidak bisa sekedar mengerti, tetapi lebih dalam lagi yaitu pemahaman secara efisien terhadap seluruh unsur yang berkaitan dengan teks tersebut. Grillet (1985: 3) berpendapat bahwa "mengerti suatu teks bacaan tidak hanya mengerti terhadap apa yang ada, tetapi lebih dalam yakni di perlukan pemahaman".

Smith (1986: 5) memberikan batasan bahwa "membaca adalah kegiatan menangkap informasi dari media tulisan". Selanjutnya, dia menegaskan bahwa "membaca pada dasamya merupakan suatu kegiatan yang bermakna dan bukan kegiatan yang mekanistis Serta pasif, melainkan suatu kegiatan yang rasional, bertujuan, yang bergantung pada motivasi dan pengetahuan pembaca sebelumnya" (Smith, 1986: 2). Hal ini berarti bahwa pembaca tidak hanya menerima informasi, tetapi berusaha untuk memberikan respon terhadap informasi diterimanya, bahkan menyumbangkan pengetahuan barn berdasarkan pengetahuan, pemahaman, dan pengalaman yang telah dimilikinya.

Goodman (1986: 63) memberikan penielasan bahwa "membaca merupakan proses pengolahan informasi grafonik, informasi gramatik, dan informasi semantik". Pengolahan informasi grafonik merupakan dasar dalam 
kegiatan membaca, yakni kegiatan menghubungkan lambang-lambang grafis dengan bunyi-bunyi bahasa. Pengolahan informasi gramatik yaitu pengolahan informasi yang berkenaan dengan struktur gramatikal bahasa, sedangkan pengolahan informasi semantik yaitu pengolahan aspek makna dari simbol grafonik dan gramatika. Dengan demikian, seorang pembaca dituntut untuk memiliki pengetahuan kebahasaan yang memadal serta pengalaman yang cukup tentang topik yang dibacanya agar is mendapatkan sesuatu yang bermanfaat dari kegiatan tersebut.

Carrol dalam Haris (1981: 264-265) mempertegas lagi bahwa "membaca merupakan proses interaksi antara Tatar belakang pengalaman kejiwaan pembaca dengan informasi leksikal dan gramatikal yang terkandung dalam simbol-simbol grafis dalam upaya memperoleh pecan penulis". Dikatakan demikian, karena untuk dapat menangkap makna yang terkandung dalam suatu bacaan, salah satunya dipengaruhi oleh faktor pengalaman pembaca, balk itu situasi atau hal-hal tertentu maupun pemahaman terhadap struktur kebahasaan.

Membaca dapat juga dianggap sebagai suatu proses untuk memahami yang tersirat dan tersurat, melihat pikiran yang terkandung di dalam kata-kata yang tertulis. Tingkatan hubtmgan antara makna yang hendak dikemukakan oleh penulis dan penafsiran atau interpretasi pembaca turut menentukan ketepatan membaca. Makna bacaan tidak terletak pada halaman tertulis, tetapi pada pikiran pembaca. Demikianlah makna itu akan berubah, karena setup pembaca memiliki pengalaman yang berbeda-beda yang dia pergunakan sebagai alat untuk menginterpretasikan kata-kata tersebut (Anderson, 1972: 211).

Berdasarkan beberapa pengertian di atas, dapat disimpulkan bahwa membaca merupakan aktivitas untuk memperoleh informasi dari bahan tertulls melalul suatu interaksi antara pembaca dan penulis yang diwakill oleh tulisannya. Dalam interaksi tersebut tedadi kontak antara karakteristik yang dimiliki pembaca dan karakteristik yang dimiliki penulis. Kontak antara kedua karakteristik itu akan melahirkan pemahaman pembaca terhadap ide atau gagasan penulis. Hal itu berarti membaca bukan semata-mata menyuarakan bahasa dan mengikuti baris demi baris tulisan tersebut, tetapi 


\section{Faqih Hakim Hasibuan}

berusaha untuk memperoleh pesan, amanat, dan makna yang disampaikan penulis melalul media bacaan secara utuh dan menyeluruh.

Membaca merupakan suatu proses yang sangat kompleks, karena melibatkan berbagai komponen yang ada dalam diri pembaca. Dikatakan demikian, karena dalam proses ini terlibat berbagai unsur seperti ingatan, pengalaman, otak, pengetahuan, kompetensi bahasa, keadaan psikologis, emosional, dan panca indra (mata). Semua unsur atau komponen tersebut Saling bekerja sama dengan maksud untuk memahaim makna bacaan.

Secara singkat dapat dikatakan bahwa membaca adalah "bringing meaning to and getting meaning from printed or written material" memtik serta memahami arti atau makna yang terkandung suatu wacana.

\section{Tujuan Pembelajaran Membaca Pemahaman di Kelas VI SD Swasta PAB Medan Estate}

Tujuan pembelajaran membaca di SMP adalah tercapainya "kemahirwacanaan", yaitu kemampuan membaca yang ditandai oleh adanya kemampuan pembaca dalam memaknai, meringkas, menjelaskan dan menyintesiskan informasi yang terdapat di dalam bacaan (Joni, 1990: 1-2). Tujuan ini ni berlaku pula pada tujuan pembelajaran membaca bacaan yang diajarkan di kelas VI SD Swasta PAB Medan Estate, yakni "agar siswa mampu membaca cepat dan memahami isinya, serta dapat mernaknai kata-kata sukar, baik dengan menggunakan kamus maupun dengan sumber-sumber lainnya".

Pembelajaran membaca pemahaman di kelas VI SD Swasta PAB Medan Estate realisasinya dituangkan ke dalam dua butir materi pembelajaran yang tercantum pada BSNP 2006, yaitu (1) membaca cepat teks bacaan untuk menemukan gagasan-gagasan (ide-ide) pokok dan menjawab pertanyaan-pertanyaan yang diajukan, dan (2) membaca pemahaman kemudian menceritakan kembali isi bacaan (BSNP. 2006: 459466).

\section{Penutup}

Berdasarkan uraian di atas, dapat disimpulkan bahwa penyajian 
pembelajaran membaca pemahaman dan menceritakan kembali isi bacaan di kelas VI SD Swasta PAB Medan Estate hendaknya dilaksanakan secara terpadu, yaitu terpadu antara kegiatan membaca, menulis, berbicara, dan menyimak. Pembelajaran membaca difokuskan pada penemuan ide-ide pokok pada setiap paragraf, penemuan pola hubungan antaride, dan penemuan ide utama bacaan. Pembelajaran menulis difokuskan pada penulisan kembali atau menceritakan kembali isi bacaan, sedangkan pembelajaran berbicara dan menyimak akan terjadi jika dalam pembelajaran ini dilanjutkan pada upaya untuk menceritakan kembali secara lisan di depan kelas.

Tujuan yang ingin dicapai dalam pembelajaran membaca pernahaman dan menceritakan kembali isi bacaan ini, meliputi tujuan yang bersifat kognitif, afektif, dan psikomotorik. Ketiga aspek tujuan tersebut pencapaiannya dilakukan secara integratif

Tujuan yang ingin dicapai dalam penelitian ini hanya difokuskan pada kemampuan siswa yang bersifat kognitif dan psikomotorik, yang meliputi kemampuan menemukan ide pokok pada setiap paragraf, menemukan pola hubungan antaride, menemukan ide utama bacaan, menuangkan ide lama dan ideide pokok paragraf ke dalam peta struktur isi bacaan, dan kemampuan menceritakan kembali isi bacaan. Kemampuan lain yang bersifat afektif dimungkinkan ikut tercapai di dalam pembelajaran, akan tetapi aspek tersebut tidak termasuk bagian yang akan diteli sehingga munculnya kemampuan yang bersifat afektif pada siswa, semata-mata hanya merupakan dampak pengiring dari adanya kemampuan yang bersifat kognitif dan motorik.

\section{Daftar Pustaka}

Admin. "Model Pendidikan Berpikir Kritis-Kreatif untuk Siswa SMP". [Online].

Diakses dari http://www.infodiknas.com/model-pendidikan-berpikirkritis-kreatif-untuk-siswa-sekolah-dasar/.Post, 24 Juli 2009.

Alexander, Estill, Teaching Reading. Illinois: Scott, Foresman and Company, 1988.

Arikunto, Suharsimi, Prosedur Penelitian. Jakarta : Rineka Cipta, 1998. 
Faqih Hakim Hasibuan

Departemen Pendidikan Nasional Direktorat Jendral Pendidikan Dasar dan Menengah Direktorat Tenaga Kependidikan, 2003. Pendidikan Tindakan Kelas. Jakarta : Depdiknas.

Depdikbud, Kamus Besar Bahasa Indonesia. Jakarta: Balai Pustaka, 2000.

Iskandarwassid. Sunendar, Dadang. Strategi Pembelajaran Bahasa. Bandung: PT Remaja Rosdakarya, 2008.

Keraf, Goys. Komposisi. Jakarta: Nusa Indah, 1984.

Mulyasa, E. Kurikulum Berbasis Kompetensi. Bandung: Rosdakarya, 2002.

Muslich, Mansur. KTSP Pembelajaran Berbasis Kompetensi dan Kontekstual. Jakarta: Bumi Aksara, 2007.

Rahim, Farida. Pengajaran Membaca di Sekolah Dasar. Jakarta: Bumi Aksara, 2007.

Saefullah, Rendahnya Minat Baca Masyarakat. Bandung: Pikiran Rakyat Juni 2001.

Sanjaya, Wina, Strategi Pembelajaran Berorientasi Standar Proses Pendidikan. Jakarta: Kencana, 2006.

Sudarsono, Sistem Membaca Cepat dan Efektif, Gramedia Pustaka Utama, 1994.

Sudrajat, Ahmad. (2008). Teori Belajar Kontruktivisme. [Online]. Tersedia. http://akhmadsudrajat.wordpress.com/2008/08/20/teoribelajarkontruktivisme/

Subino, Konstruksi dan Analisis Tes. Suatu Pengantar kepada Teori Tes dan Pengukuran. Jakarta: Depdikbud, 1982.

Supriyanto, "Kemampuan membaca", Bandung: Pikiran Rakyat 2 September 2001.

Surakhmad, Pengantar Penelitian I/miah, Bandung: Tarsito, 1998. 